\title{
Distribution of activity of hydrolytic enzymes in the digestive tract of rabbits
}

\author{
BY M. MAROUNEK AND S. J. VOVK* \\ Institute of Animal Physiology and Genetics, Czech Academy of Sciences, \\ 10400 Prague 10 - Uhřněves, Czech Republic \\ AND V. SK ŘIVANOVÁ \\ Research Institute of Animal Production, 10400 Prague 10 - Uhřñěves, Czech Republic
}

(Received 14 February 1994 - Revised 23 May 1994 - Accepted 7 July 1994)

\begin{abstract}
Activities of twelve hydrolytic enzymes in the digestive tract of young rabbits before weaning ( 4 weeks old) and adult rabbits ( 3 months old) were measured. The principal digestive enzymes in both groups of rabbits appeared to be amylase $(E C$ 3.2.1.1), maltase $(E C$ 3.2.1.20), pectinase $(E C 3.2 .1 .15)$ and proteinases. The stomach of young rabbits contained most of the lipolytic activity and $45 \cdot 7 \%$ of the total proteolytic activity of the digestive tract. The highest specific activities (per $g$ digesta) of amylase, maltase and proteinase in young rabbits were found in the small intestine. Total activities (per segment) of amylase and maltase in the small intestine and the caecum were similar. Activities of cellulase $(E C$ 3.2.1.4), inulinase $(E C$ 3.2.1.7) and $\beta$-glucosidase $(E C 3.2 .1 .21)$ were low and activity of pectinase was fairly high in all segments of the digestive tract. The highest activity of urease (EC 3.5.1.5) was found in the caecum. Enzymic profiles of the colonic chymus resembled those of the caecum. Total hydrolytic activity was lower in the colon than in the caecum. Specific activities of amylase and invertase $(E C$ 3.2.1.26) were lower and those of inulinase and lactase $(E C$ 3.2.1.23) higher in 4week-old rabbits than in 3-month-old rabbits. Gastric proteinase represented almost half of the total proteolytic activity of the digestive tract, whereas lipolytic activity of gastric contents was not found in measurable quantities in adult rabbits. The caecal contents of adult rabbits contained most of the total activity of lipase $(E C$ 3.1.1.3), cellulase, xylanase $(E C$ 3.2.1.32), pectinase, lactase, invertase, $\beta$ glucosidase and urease present in the digestive tract. The presence of microbial enzymes (pectinase, cellulase, xylanase, inulinase and urease) in non-fermentative segments of the digestive tract reflects the reingestion of caecal contents during coprophagy.
\end{abstract}

Hydrolytic enyzmes: Digestive tract: Rabbit

Rabbits can be successfully raised on various diets composed of forages, agricultural byproducts, concentrates and protein supplements. The digestibility of organic matter of feeds is lower in rabbits than in other herbivorous animals, primarily due to lower digestion of crude fibre (Slade \& Hintz, 1969; Sakaguchi et al. 1987). The degradation of organic matter in the digestive tract of rabbits involves a number of hydrolytic reactions which are catalysed by enzymes of endogenous and/or microbial origin. It is generally assumed that hydrolytic activity and digestive volume correlate positively with the digestion efficiency. The nutritive value of rabbit diets, thus, can be improved by enzyme supplementation as suggested by Yu \& Tsen (1993), and by use of other dietary additives influencing the digesta enzyme activity. Several studies have attempted to measure activities of hydrolytic enzymes in the digestive tract of rabbits. Griffiths \& Davies (1963) demonstrated a high activity of

* Present address: Ukrainian Institute of Physiology and Biochemistry of Animals, 290034 Lvov, Ukraine. 
amylase (EC 3.2.1 .1) in rabbit soft faeces. Forsythe \& Parker (1985) found a high activity of urease $(E C 3.5 .1 .5)$ in the rabbit caecum and a low level in the stomach. Makkar \& Singh (1987) compared enzymic profiles of the rabbit caecum and bovine rumen contents. The activities of urease, amylase and protease were higher and activity of cellulase (EC 3.2.1.4) lower in the rabbit caecum than in the rumen. Moreau et al. (1988), Borel et al. (1991) and Levy et al. (1991) described rabbit gastric lipase (EC 3.1.1.3). Alus \& Edwards (1977) studied the postnatal development of intestinal disaccharidases, amylase and proteases in rabbits. Their results indicate that activities of invertase (EC 3.2.1.26), maltase $(E C 3.2 .1 .20)$ and amylase increase from birth to weaning, whereas activity of lactase (EC 3.2.1.23) decreases in this time interval. Information on activity of other hydrolytic enzymes is scarce. A high digestibility of pectin reported by Gidenne et al. (1991 a) suggests a high activity of pectinolytic enzymes in the rabbit digestive tract. A similar general conclusion can be drawn on the basis of the high digestibilities of protein (Slade \& Hintz, 1969; Gidenne, 1992) and starch (Gidenne \& Perez, 1993) and the low digestibility of cellulose (Gidenne, 1992). We have not found reports on activity of hemicellulases in rabbits in the available literature. Xylose, which is the principal monomeric unit of hemicelluloses, was the least-degraded neutral sugar in the rabbit digestive tract (Gidenne et al. 1991 ; Gidenne, 1992). Low digestibility of hemicellulose $(10 \cdot 7-25 \cdot 4 \%)$ was reported by Gidenne et al. (1991 b). In contrast, Sakaguchi et al. (1992) found that $57.9 \%$ of hemicellulose was digested in rabbits.

The purpose of the present study was to measure the digesta weight and activities of twelve hydrolytic enzymes in the rabbit stomach, small intestine, caecum and colon. The study aimed (1) to evaluate the hydrolytic activity of these digestive tract segments, and (2) to compare adult rabbits and rabbits before weaning in this respect. A potential benefit of enzyme supplementation of rabbit rations will be briefly discussed.

\section{MATERIALS AND METHODS}

Animals and diets

All rabbits were New Zealand $\times$ Californian hybrids, obtained from a rabbitry with the capacity of 250 does. Rabbits were kept in stainless steel mesh cages $(400 \mathrm{~mm} \times$ $650 \mathrm{~mm} \times 320 \mathrm{~mm}$ ) in a room with natural lighting at a temperature of $16 \pm 2^{\circ}$ and relative humidity of about $70 \%$. Does with their young were housed individually in cages with nest boxes; other rabbits were housed four per cage. Seven young rabbits from one litter remained continuously with the non-pregnant dam until day 28 when they were killed. Rabbits had free access to a commercial granulated feed containing wheat, barley, oats, maize, soya-bean meal, dehydrated lucerne (Medicago sativa) and a vitamin-mineral supplement. The feed contained $(\mathrm{g} / \mathrm{kg})$ : crude protein 176 , fat 22 and crude fibre 126 . The feed did not contain any coccidiostat. Eleven rabbits of the same breed, 3 months old, were fed on similar granulated concentrate feed, differing in the proportions of the components mentioned above. The feed contained $(\mathrm{g} / \mathrm{kg})$ : crude protein 147, fat 22 and crude fibre 132 . No attempt to prevent coprophagy was made.

\section{Sampling of digesta}

Rabbits were killed approximately $4 \mathrm{~h}$ after the morning feed, weighed and segments of their digestive tract (stomach, small intestine, caecum and colon) were emptied by gentle squeezing. The $\mathrm{pH}$ of the digesta was measured immediately. Contents of individual segments were weighed and then stored under $\mathrm{CO}_{2}$ in hermetically sealed bottles at $-40^{\circ}$ until analysed. 
Table 1. Weight, dry matter $(D M)$ content and $p H$ of digesta from different segments of the digestive tract of rabbits $\dagger$

(Mean values and standard deviations for seven 4-week-old rabbits and eleven 3-month-old rabbits)

\begin{tabular}{|c|c|c|c|c|c|c|c|c|}
\hline & \multicolumn{2}{|c|}{ Stomach } & \multicolumn{2}{|c|}{ Small intestine } & \multicolumn{2}{|c|}{ Caecum } & \multicolumn{2}{|c|}{ Colon } \\
\hline & Mean & SD & Mean & SD & Mean & SD & Mean & SD \\
\hline \multicolumn{9}{|c|}{ 4-week-old rabbits } \\
\hline Weight (g) & $38 \cdot 0$ & $6 \cdot 4$ & $10 \cdot 1$ & $3 \cdot 8$ & $28 \cdot 2$ & $4 \cdot 1$ & $7 \cdot 4$ & $1 \cdot 2$ \\
\hline $\mathrm{DM}(\mathrm{g} / \mathrm{kg})$ & 234 & 16 & 117 & 22 & 213 & 58 & 248 & 23 \\
\hline $\mathrm{pH}$ & $2 \cdot 88$ & 0.73 & $6 \cdot 50$ & 0.23 & $5 \cdot 52$ & 0.19 & 5.95 & 0.56 \\
\hline \multicolumn{9}{|c|}{ 3-month-old rabbits } \\
\hline Weight (g) & $96 \cdot 9 * *$ & $12 \cdot 2$ & $16 \cdot 9 * *$ & $3 \cdot 2$ & $116 \cdot 7^{* *}$ & $27 \cdot 1$ & $29 \cdot 8^{* *}$ & $7 \cdot 6$ \\
\hline $\mathrm{DM}(\mathrm{g} / \mathrm{kg})$ & 198 & 34 & $80^{* *}$ & 20 & 208 & 65 & $277^{* *}$ & 14 \\
\hline $\mathrm{pH}$ & 2.58 & 0.48 & $7 \cdot 09^{* *}$ & $0 \cdot 17$ & $6.05^{* *}$ & $0 \cdot 19$ & $6 \cdot 73^{* *}$ & 0.22 \\
\hline
\end{tabular}

** Values were significantly different from those of 4-week-old rabbits: $P<0.01$.

$\dagger$ Rabbits were killed $4 \mathrm{~h}$ after the morning feed. For diets see p. 464.

\section{Analyses}

Activities of amylase, cellulase, xylanase ( $E C$ 3.2.1.32), pectinase ( $E C$ 3 3.2.1.15), inulinase (EC 3.2.1.7), urease and proteinases were assayed according to Kopečný \& Bartoš (1990) using soluble starch, carboxymethylcellulose, oat-spelt xylan, citrus pectin, inulin, urea and azocasein as substrates respectively. Contents of the stomach were diluted with a citrate-phosphate buffer ( $\mathrm{pH} 2.5)$, whereas contents of other parts of the digestive tract were diluted with a phosphate buffer $(\mathrm{pH} 7 \cdot 0)$. Liberated reducing sugars were determined by reaction with Somogyi reagent (Somogyi, 1952), ammonia with Nessler solution, and azocasein fragments colorimetrically at $440 \mathrm{~nm}$. Activities of lactase, invertase and maltase were measured in the same way, using lactose, sucrose and maltose as substrates. Glucose liberated from disaccharides was measured by the glucose oxidase - peroxidase method. A commercial kit from Lachema (Brno, Czech Republic) was used. Activity of $\beta$-glucosidase (EC 3.2.1.21) was estimated by measuring the liberation of $p$-nitrophenol from $p$ nitrophenyl- $\beta$-D-glucopyranoside (Williams \& Withers, 1981). Activity of lipase was measured by the modified method of Bier (1955). Samples of digesta $(0.1 \mathrm{~g})$ were incubated with $0.0025 \mathrm{M}$-Tris- $\mathrm{HCl}$ buffer containing $0.025 \mathrm{M}-\mathrm{CaCl}_{2}(0.8 \mathrm{ml}), 0.2 \mathrm{M}-\mathrm{Na}_{2} \mathrm{HPO}_{4}(0.1 \mathrm{ml})$ and emulsified tributyrin $(1.0 \mathrm{ml})$. The emulsion was prepared from tributyrin $(10 \mathrm{ml})$, Tween $80(1 \mathrm{ml})$ and water $(100 \mathrm{ml})$. The reaction mixture was incubated $\left(37^{\circ}, 1 \mathrm{~h}\right)$ and then centrifuged. Liberated butyrate was determined by titration, after steam distillation in the Markham apparatus. Again, the estimation of the gastric lipolytic activity was performed at low $\mathrm{pH}$.

Dry matter of digesta was determined by heating at $105^{\circ}$ for $16 \mathrm{~h}$. The significance of differences was evaluated by Student's $t$ test.

RESULTS

Table 1 presents weights, DM contents and $\mathrm{pH}$ values of digesta from the stomach, small intestine, caecum and colon of rabbits. Digesta represented on average $120 \mathrm{~g} / \mathrm{kg}$ body weight of young rabbits (before weaning) and $93 \mathrm{~g} / \mathrm{kg}$ body weight of adult rabbits (3 months old). 
Table 2. Distribution of activity of hydrolytic enzymes in the digestive tract of 4-week-old rabbits

(Mean values and standard deviations for seven rabbits)

\begin{tabular}{|c|c|c|c|c|c|c|c|c|}
\hline \multirow[b]{2}{*}{ Enzyme } & \multicolumn{2}{|c|}{ Stomach } & \multicolumn{2}{|c|}{ Small intestine } & \multicolumn{2}{|c|}{ Caecum } & \multicolumn{2}{|c|}{ Colon } \\
\hline & Mean & SD & Mean & SD & Mean & SD & Mean & SD \\
\hline \multicolumn{9}{|l|}{ Specific activity (per g digesta) } \\
\hline Lipaset $(E C 3,1.1 .3)$ & $2 \cdot 2$ & $1 \cdot 3$ & 1.6 & 0.3 & 1.6 & 0.3 & $2 \cdot 6$ & 0.2 \\
\hline Amylase + (EC 3.2.1.1) & 0 & - & 55.5 & 4.8 & 20.7 & $4 \cdot 4$ & 22.5 & $7 \cdot 2$ \\
\hline Cellulasef $(E C 3.2 .1 .4)$ & 0 & - & $2 \cdot 4$ & 0.3 & 3.5 & 0.3 & $2 \cdot 9$ & $0 \cdot 2$ \\
\hline Xylanase $\ddagger(E C 3.2 .1 .32)$ & 0 & - & $8 \cdot 4$ & 0.8 & $13 \cdot 2$ & 2.9 & $15 \cdot 9$ & 1.5 \\
\hline Pectinase $(E C 3.2 .1 .15)$ & 6.7 & $1 \cdot 1$ & $18 \cdot 6$ & $2 \cdot 0$ & $18 \cdot 7$ & 1.8 & $33 \cdot 7$ & $4 \cdot 4$ \\
\hline Inulinase $f(E C 3.2 .1 .7)$ & 0 & - & $6 \cdot 1$ & 0.8 & 4.5 & 0.9 & $6 \cdot 3$ & $1 \cdot 1$ \\
\hline Lactase $\$(E C 3.2 .1 .23)$ & 0 & - & $8 \cdot 0$ & 0.6 & 6.0 & $1 \cdot 1$ & $6 \cdot 2$ & $0 \cdot 7$ \\
\hline Invertase $(E C 3.2 .1 .26)$ & 0.6 & $0 \cdot 1$ & 7.6 & 1.2 & $3 \cdot 2$ & 0.5 & $3 \cdot 2$ & $1 \cdot 1$ \\
\hline Maltase§ $(E C 3.2 .1 .20)$ & 0 & - & 45.4 & $10 \cdot 2$ & 18.9 & $5 \cdot 6$ & $21 \cdot 3$ & $9 \cdot 0$ \\
\hline$\beta$-Glucosidase $(E C$ 3.2.1.21) & 0 & - & 0.8 & 0.2 & 2.8 & 0.2 & 3.5 & 0.6 \\
\hline Urease $\|(E C 3.5 .1 .5)$ & 0 & - & $1 \cdot 4$ & 0.3 & 64.8 & 8.6 & 58.9 & $9 \cdot 6$ \\
\hline Proteinases $\mid$ & 40.8 & 1.9 & $65 \cdot 6$ & 27.8 & $32 \cdot 2$ & $2 \cdot 0$ & $36 \cdot 7$ & $6 \cdot 3$ \\
\hline \multicolumn{9}{|l|}{ Total activity (per segment) } \\
\hline Lipase $\dagger$ & 84 & 21 & 16 & 2 & 45 & 3 & 19 & 2 \\
\hline Amylase $\ddagger$ & 0 & - & 560 & 47 & 584 & 48 & 166 & 24 \\
\hline Cellulase & $\mathbf{0}$ & - & 24 & 2 & 99 & 3 & 21 & 2 \\
\hline Xylanasef & 0 & - & 85 & 8 & 372 & 11 & 118 & 5 \\
\hline Pectinase & 255 & 24 & 188 & 18 & 527 & 19 & 249 & 13 \\
\hline Inulinase & 0 & - & 62 & 8 & 127 & 10 & 47 & 2 \\
\hline Lactase $\S_{+}^{+}$ & 0 & - & 81 & 5 & 169 & 11 & 46 & 3 \\
\hline Invertase $\$$ & 23 & 3 & 78 & 13 & 90 & 5 & 24 & 3 \\
\hline Maltase§ & 0 & - & 458 & 99 & 533 & 61 & 157 & 29 \\
\hline$\beta$-Glucosidase $\S$ & 0 & - & 8 & 2 & 79 & 4 & 26 & 3 \\
\hline Urease $\|$ & 0 & - & 14 & 2 & 1827 & 93 & 436 & 32 \\
\hline Proteinases & 1550 & 32 & 662 & 278 & 908 & 21 & 272 & 21 \\
\hline
\end{tabular}

$\dagger$ Expressed as mmol butyrate liberated from tributyrine/h.

$\ddagger$ The assay was based on the increase in reducing power, calibrated by corresponding monomeric sugars. The activity was expressed as mg sugar liberated/h.

$\S$ Expressed as mg glucose liberated $/ \mathbf{h}$.

$\|$ Expressed as $\mathrm{mg}$ urea hydrolysed/h.

I Expressed as mg azocasein decomposed/h.

Table 2 summarizes data on the activity of twelve hydrolytic enzymes in the contents of the digestive tract of rabbits before weaning. The gastric lipase in young rabbits represented most of the lipolytic activity of the whole digestive tract. The stomach of young rabbits contained almost half of the total proteolytic activity, $20.9 \%$ of the total pectinolytic activity and a low but measurable activity of invertase. The small intestine and caecum of young rabbits contained highly active amylase and maltase. Specific activity of proteinases (per g digesta) was higher in the small intestine than that in other parts of the digestive tract. The caecum contained most of the activity of cellulase, xylanase, $\beta$-glucosidase and urease. The colonic contents exhibited the highest specific activities of lipase, xylanase, pectinase, inulinase and $\beta$-glucosidase. Total activities of hydrolytic enzymes were, however, lower in the colon than in the caecum.

Table 3 presents data on the activity of hydrolytic enzymes in the contents of digestive tract segments of adult rabbits. In the stomach, activities of hydrolytic enzymes other than proteinases, pectinase and invertase were absent or below the detection limit of a method

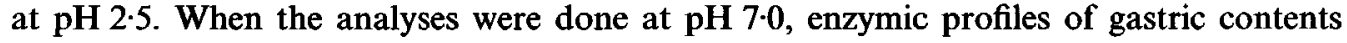


Table 3. Distribution of activity of hydrolytic enzymes in the digestive tract of 3-monthold rabbits

(Mean values and standard deviations for eleven rabbits)

\begin{tabular}{|c|c|c|c|c|c|c|c|c|}
\hline & \multicolumn{2}{|c|}{ Stomach } & \multicolumn{2}{|c|}{ Small intestine } & \multicolumn{2}{|c|}{ Caecum } & \multicolumn{2}{|c|}{ Colon } \\
\hline & Mean & SD & Mean & SD & Mean & SD & Mean & SD \\
\hline \multicolumn{9}{|c|}{ Specific activity (per g digesta) } \\
\hline Lipase $(E C 3.1 .1 .3)$ & 0 & - & $1 \cdot 3$ & $0 \cdot 3$ & 1.7 & 0.2 & $3 \cdot 3 * *$ & 0.3 \\
\hline $\begin{array}{l}\text { Amylaseł } \\
(E C \text { 3.2.1.1) }\end{array}$ & $\mathbf{0}$ & - & $105 \cdot 7^{* *}$ & $11 \cdot 2$ & $26 \cdot 4^{* *}$ & $3 \cdot 2$ & $25 \cdot 9$ & $5 \cdot 8$ \\
\hline $\begin{array}{l}\text { Cellulase } \$ \\
(E C 3.2 .1 .4)\end{array}$ & 0 & - & $1.7 * *$ & 0.4 & $2 \cdot 6^{* *}$ & 0.4 & $1 \cdot 9 * *$ & 0.3 \\
\hline $\begin{array}{l}\text { Xylanase } \neq \\
\text { (EC 3.2.1.32) }\end{array}$ & 0 & - & 8.7 & 0.8 & $12 \cdot 9$ & $2 \cdot 3$ & $12 \cdot 4^{* *}$ & $1 \cdot 4$ \\
\hline $\begin{array}{l}\text { Pectinase } \$ \\
(E C 3.2 .1 .15)\end{array}$ & $10 \cdot 1^{* *}$ & 1.9 & $22 \cdot 7$ & 3.6 & $26 \cdot 1^{* *}$ & $4 \cdot 2$ & $24 \cdot 3$ & 9.8 \\
\hline $\begin{array}{l}\text { Inulinase } \ddagger \\
(E C 3.2 .1 .7)\end{array}$ & 0 & - & $2 \cdot 3^{* *}$ & 0.7 & $2 \cdot 2^{* *}$ & 0.7 & $2 \cdot 0 * *$ & 0.7 \\
\hline $\begin{array}{l}\text { Lactase } \\
(E C 3.2 .1 .23)\end{array}$ & 0 & - & $3 \cdot 4^{* *}$ & 1.0 & $4 \cdot 5^{* *}$ & 0.5 & $2 \cdot 8^{* *}$ & 0.9 \\
\hline $\begin{array}{l}\text { Invertase } \\
(E C 3.2,1.26)\end{array}$ & $2 \cdot 5^{* *}$ & 0.7 & $15 \cdot 7 * *$ & 1.9 & $7 \cdot 7^{* *}$ & $1 \cdot 5$ & $7 \cdot 5^{* *}$ & 1.5 \\
\hline $\begin{array}{l}\text { Maltase } \\
(E C \text { 3.2.1.20) }\end{array}$ & $\mathbf{0}$ & - & $69-1 * *$ & 14.0 & $24 \cdot 2$ & $8 \cdot 4$ & $19 \cdot 0$ & $6 \cdot 1$ \\
\hline $\begin{array}{c}\beta \text {-Glucosidaseई } \\
(E C 3.2 .1 .21)\end{array}$ & 0 & - & 0.9 & $0 \cdot 3$ & $3 \cdot 9 * *$ & 0.5 & $3 \cdot 4$ & $1 \cdot 8$ \\
\hline Urease $\|(E C 3.5 .1 .5)$ & 0 & - & $3 \cdot 7^{* *}$ & 1.4 & $18 \cdot 0^{* *}$ & $8 \cdot 0$ & $12 \cdot 9^{* *}$ & 5.5 \\
\hline Proteinases & 44.6 & $6 \cdot 8$ & 69.6 & $7 \cdot 6$ & $25 \cdot 9$ & $8 \cdot 3$ & $27 \cdot 0^{* *}$ & 8.5 \\
\hline \multicolumn{9}{|c|}{ Total activity (per segment) } \\
\hline Lipase $\dagger$ & 0 & - & $22 * *$ & 3 & $198^{* *}$ & 20 & $98 * *$ & 10 \\
\hline Amylase & 0 & - & $1786^{* *}$ & 119 & $3081^{* *}$ & 282 & $772^{* *}$ & 149 \\
\hline Cellulase $\ddagger$ & 0 & - & $29^{* *}$ & 3 & $303^{* *}$ & 33 & $57^{* *}$ & 7 \\
\hline Xylanase & 0 & - & $147^{* *}$ & 10 & $1505^{* *}$ & 209 & $370^{* *}$ & 33 \\
\hline Pectinase & $979 * *$ & 96 & $384 * *$ & 36 & $3046 * *$ & 375 & $724^{* * *}$ & 249 \\
\hline Inulinase: & 0 & - & $39^{* *}$ & 6 & $257^{* *}$ & 63 & 60 & 17 \\
\hline Lactase§ & 0 & - & $57^{* *}$ & 10 & $525^{* *}$ & 46 & $83 * *$ & 23 \\
\hline Invertase§ & $242^{* *}$ & 30 & $265^{* * *}$ & 20 & $899^{* *}$ & 129 & $223^{* *}$ & 36 \\
\hline Maltase§ & 0 & - & $1168^{* *}$ & 149 & $2824^{* *}$ & 756 & $566^{* *}$ & 152 \\
\hline$\beta$-Glucosidase $\$$ & 0 & - & $15^{* *}$ & 5 & $455^{* *}$ & 47 & $101^{* *}$ & 46 \\
\hline Urease $\|$ & 0 & - & $63^{* *}$ & 13 & 2100 & 713 & 384 & 139 \\
\hline Proteinases & $4322 * *$ & 272 & $1176^{* *}$ & 80 & $3023^{* *}$ & 743 & $805^{* *}$ & 216 \\
\hline
\end{tabular}

** Values were significantly different from those of 4-week-old rabbits: $P<0.01$.

$\uparrow$ Expressed as mmol butyrate liberated from tributyrine $/ \mathrm{h}$.

† The assay was based on the increase in reducing power, calibrated against corresponding monomeric sugars. The activity was expressed as $\mathrm{mg}$ sugar liberated $/ \mathrm{h}$.

$\S$ Expressed as $\mathrm{mg}$ glucose liberated/h.

$\|$ Expressed as mg urea hydrolysed/h.

Tी Expressed as $\mathrm{mg}$ azocasein decomposed $/ \mathrm{h}$.

resembled those of the caecum (results not shown). The gastric proteolytic activity represented $46.3 \%$ of the total proteolytic activity of the digestive tract. Highly active amylase, maltase and proteinases were present in the small-intestinal digesta. Total activities of these enzymes were lower in the small intestine than in the caecum, but higher than those in the colon. The caecal digesta contained $62 \cdot 3,77 \cdot 9,74 \cdot 4,59 \cdot 3,78 \cdot 9,55 \cdot 2,79 \cdot 7$ and $82.4 \%$ of the total activity of lipase, cellulase, xylanase, pectinase, lactase, invertase, $\beta$-glucosidase and urease respectively. Enzymic profiles of colonic contents resembled those 
of the caecum. Total hydrolytic activities were $2-6$ times lower in the colon than in the caecum. Most of the differences found in specific and total activities of enzymes between young and adult rabbits were statistically significant $(P<0.01)$. Total activities (per segment) were, however, more or less influenced by extensive enlargement of digesta volume in all four digestive organs sampled.

\section{DISCUSSION}

It is obvious from our results that all hydrolases which are necessary for enzymic conversion of complex nutrients into available forms are present in the rabbit digestive tract. In addition, mucosal cells are able to split some low-molecular-weight substrates by the action of brush-border enzymes, but this was not investigated in the present study. The activity of cellulase was low in all segments of the digestive tract. This finding is consistent with a rather low digestibility of crude fibre, observed in rabbits by several authors. Slade \& Hintz (1969) found that in rabbits only $16 \cdot 2-18 \cdot 1 \%$ crude fibre was digested. A similar efficiency of fibre digestion was reported by Sakaguchi et al. (1987). Very low digestibility of crude fibre $(2.8 \%)$ was observed by Stephens (1977). The supplementation of rabbit diets with an acid-tolerant fungal cellulase, which has been suggested by Yu \& Tsen (1993), thus may improve the productive value of feeds. Also, the activities of inulinase (a fructan-splitting enzyme) and $\beta$-glucosidase were low in comparison with the activities of other saccharolytic enzymes. On the other hand, the high digestibility of pectic substances $(73 \%)$, found by Gidenne et al. $(1991 \mathrm{a})$, corresponds with the presence of highly active pectinase in all segments of the rabbit digestive tract. The activity of xylanase was relatively high in both groups of rabbits, despite the fact that digestibility of hemicelluloses in vivo seems to be low (Gidenne et al. 1991b; Gidenne, 1992). In our opinion the direct association between hemicelluloses and lignin (Jung \& Vogel, 1986), rather than lack of activity of hemicellulolytic enzymes, limits the digestibility of hemicelluloses in the rabbit digestive tract. A suitable alkali treatment of feeds might increase the digestibility of hemicelluloses more than supplementation of rabbit rations with hemicellulolytic enzymes. Purified hemicelluloses were fermented very easily by rabbit caecal contents in vitro in our preliminary experiments (results not shown).

Specific activities of amylase and invertase were lower and those of inulinase and lactase higher in young rabbits than in adult rabbits. Young rabbits at this age ( 4 weeks) consume both milk and solids and actively practise coprophagy (Alus \& Edwards, 1977). Age-related differences also include the decrease of gastric lipase and urease activity in the caecum and colon in adult rabbits. The gastric lipase activity was positively correlated with the daily fat intake in rabbits in the experiments of Borel et al. (1991). The high activity of gastric lipase in suckling rabbits enables them to utilize milk fat, which accounts for $105-167 \mathrm{~g} / \mathrm{kg}$ whole milk (Altman \& Dittmer, 1961). The digestive potential of the caecum increased with age.

Symbiotic micro-organisms inhabiting the rabbit hindgut synthesize all hydrolytic enzymes measured in the present study. Lipase, amylase, proteinases and disaccharidases are synthesized also by the host. The presence of pectinase in the stomach and cellulase, xylanase, pectinase, inulinase and urease in the small intestine can be explained by coprophagy. The coprophagy, which must be taken into account in any study on the rabbit digestive physiology, thus compensates faecal losses of microbial hydrolytic enzymes and increases the efficiency of digestion of non-starch polysaccharides and other plant constituents. The low gastric $\mathrm{pH}$, however, limits the hydrolytic action of ingested enzymes. The presence of microbial pectinase in the stomach and small intestine is consistent with the finding of Gidenne (1992) that about $50 \%$ digestible pectin disappeared before the caecum. 
The work was supported by grant No. 505/93/1283 of the Grant Agency of the Czech Republic.

\section{REFERENCES}

Altman, P. L. \& Dittmer, D. S. (1961). Blood and Other Body Fluids. Washington, DC: Federation of American Societies for Experimental Biology.

Alus, G. \& Edwards, N. A. (1977). Development of the digestive tract of the rabbit from birth to weaning. Proceedings of the Nutrition Society 36, 3A.

Bier, M. (1955). Lipases. In Methods in Enzymology, vol. 1, pp. 627-642 [S. P. Colowick and N. O. Kaplan, editors]. New York: Academic Press.

Borel, P., Armand, M., Senft, M., Andre, M., Lafont, H. \& Lairon, D. (1991). Gastric lipase - evidence of an adaptive response to dietary fat in the rabbit. Gastroenterology 100, 1582-1589.

Forsythe, S. J. \& Parker, D. S. (1985). Nitrogen metabolism by the microbial flora of the rabbit caecum. Journal of Applied Bacteriology 58, 363-369.

Gidenne, T. (1992). Effect of fibre level, particle size and adaptation period on digestibility and rate of passage as measured at the ileum and in the faeces in the adult rabbit. British Journal of Nutrition 67, 133-146.

Gidenne, T., Carré, B., Segura, M., Lapanouse, A. \& Gomez, J. (1991 a). Fibre digestion and rate of passage in the rabbit: effect of particle size and level of lucerne meal. Animal Feed Science and Technology 32, $215-221$.

Gidenne, T. \& Perez, J. M. (1993). Effect of dietary starch origin on digestion in the rabbit. 1. Digestibility measurements from weaning to slaughter. Animal Feed Science and Technology 42, 237-247.

Gidenne, T., Scalabrini, F. \& Marchais, C. (1991 b). Adaptation digestive du lapin à la teneur en constituants pariétaux du régime (Digestive adaptation of the rabbit to the level of dietary fibre). Annales de Zootechnie $\mathbf{4 0}$ 73-84.

Griffiths, M. \& Davies, D. (1963). The role of soft pellets in the production of lactic acid in the rabbit stomach Journal of Nutrition 80, 171-180.

Jung, H. G. \& Vogel, K. P. (1986). Influence of lignin on digestibility of forage cell wall material. Journal of Animal Science 62, 1703-1712.

Kopečný, J. \& Bartoš, S. (1990). Activity of hydrolases in the gastrointestinal tract of goats. Small Ruminant Research 3, 25-35.

Levy, E., Rouleau, T., Lepage, G., Smith, L., Junien, J. L. \& Roy, C. C. (1991). Partially purified rabbit gastric lipase - in vitro and in vivo experiments to assess its potential contribution to gastric and intestinal lipolysis. Nutrition Research 11, 607-619.

Makkar, H. P. S. \& Singh, B. (1987). Comparative enzymatic profiles of rabbit cecum and bovine rumen contents. Journal of Applied Rabbit Research 10, 172-174.

Moreau, H., Gargouri, Y., Lecat, D., Junien, J. L. \& Verger, R. (1988). Screening of preduodenal lipases in several mammals. Biochimica et Biophysica Acta 959, 247-252.

Sakaguchi, E., Itoh, H., Uchida, S. \& Horigome, T. (1987). Comparison of fibre digestion and digesta retention time between rabbits, guinea-pigs, rats and hamsters. British Journal of Nutrition 58, 149-158.

Sakaguchi, E., Kaizu, K. \& Nakamichi, M. (1992). Fibre digestion and digesta retention from different physical forms of the feed in the rabbit. Comparative Biochemistry and Physiology 102A, 559-563.

Slade, L. M. \& Hintz, H. F. (1969). Comparison of digestion in horses, ponies, rabbits and guinea pigs. Journal of Animal Science 28, 842-843.

Somogyi, M. (1952). Notes on sugar determination. Journal of Biological Chemistry 195, 19-23.

Stephens, A. G. (1977). Digestibility and coprophagy in the growing rabbit. Proceedings of the Nutrition Society 36, 4A.

Williams, A. G. \& Withers, S. E. (1981). Hemicellulose-degrading enzymes synthesized by rumen bacteria. Journal of Applied Bacteriology 51, 375-385.

Yu, B. \& Tsen, H. Y. (1993). An in vitro assessment of several enzymes for the supplementation of rabbit diets. Animal Feed Science and Technology 40, 309-320. 